This PDF is a selection from a published volume from the National Bureau of Economic Research

Volume Title: Governance, Regulation, and Privatization in the Asia-Pacific Region, NBER East Asia Seminar on Economics, Volume 12

Volume Author/Editor: Takatoshi Ito and Anne O. Krueger, editors

Volume Publisher: University of Chicago Press

Volume ISBN: 0-226-38679-1

Volume URL: http://www.nber.org/books/ito_04-1

Conference Date: June 28-30, 2001

Publication Date: January 2004

Title: Government Commitment and the Outcome of Privatization in China

Author: Yang Yao

URL: http://www.nber.org/chapters/c10192 


\title{
Government Commitment and the Outcome of Privatization in China
}

\author{
Yang Yao
}

If there was any significant change in the Chinese economic structure in the 1990 s, it had to be privatization. By one report, 80 percent of the firms at or below county level were privatized by the end of 1998 (Zhao 1999). ${ }^{1}$ Privatization also spread to large state-owned enterprises (SOEs) in large cities. A recent study (International Finance Corporation [IFC], forthcoming) found that 70 percent of the SOEs in the eleven sample cities had taken some form of privatization. However, the performance record of privatization varied from city to city. A question then arises as to why such performance disparity occurred. In this paper, we first use recent survey data to assess the regional performance disparity and then explain it. We ascribe the disparity to the different degrees of local government commitment to privatization.

Privatization transfers the legal ownership of a public firm to private hands, making the latter the residual claimant. However, privatization by no means binds the government's hand from intervening, nor does it bind bureaucrats' hands from grabbing. One serious problem that private firms encounter in China is the excessive and irregular charges imposed by local governments. For example, the survey that this study will draw data from found that the amount of fees is equivalent to the amount of regular taxes among the surveyed firms (Garnaut et al. 2001). Privatization cannot exempt a firm from the excessive charges. In other words, privatization does not mean the establishment of the rule of law. The lack of rule of law has been identified by some authors as the most important factor that led to

Yang Yao is professor at the China Center for Economic Research, Beijing University.

1. A county-level unit does not necessarily mean a rural area. Many counties have turned into urban areas and changed their administrative status to "city," although they are still regarded as county-level administrative units. 
Russia's economic failures (e.g., Shleifer 1997). However, the establishment of rule of law is not always in the politician's interests; and, even if it is, it may turn out not to be time-consistent for the politician. On the other hand, having been through frequent policy changes by the government, the manager of the firm may not trust it even if the establishment of the rule of law is in the politician's interests. Therefore, the politician has to establish a credible commitment at the time of privatization just to induce good performance or even to make privatization happen in the first place.

The paper is organized as follows. Section 10.1 presents a brief review of the Chinese government's policy toward privatization in the last twenty years. Section 10.2 shows the regional disparity in firm performance by presenting the econometric results on six cities. Section 10.3 constructs a theoretical model to explain the relationship between government commitment and post-privatization performance. Section 10.4 presents the government reform experience in Shunde, Guangdong province, to provide an illustration of the theory. Section 10.5 concludes the paper with a discussion of the implications of the study.

\subsection{Government Policy toward Privatization}

Reform of the SOEs has been a major theme of China's reform efforts since the urban reform was launched in 1984. Throughout the 1980s, although there were calls for privatization, government emphasis was on how to improve the performance of the SOEs by changing their internal governance. Inspired by the success of the household responsibility system in the countryside, one major effort was to introduce a contracting system into the SOEs. In such a system, the manager signed a contract with the government on specific terms. The manager promised to maintain a certain record of the firm's financial position, including sales, profitability, capital accumulation, and so on. In return, the government promised the manager certain returns, such as a commission, out of the profit. One problem with the contracting system was that the manager's terms were asymmetric: the manager would be rewarded for his successes, but would not be punished credibly for his failure. As a result, personal collateral was introduced into the system.

A further development was to adopt a lease contract: the manager leased the firm by paying the government a fixed proportion of the firm's profit. The first significant case of a lease contract was the Wuhan Motor Engine Factory in 1986, wherein three people invested 34,000 yuan as collateral to lease the factory. By the end of the 1980s, lease contracts were encouraged by the government as a means of reforming small SOEs. A State Council regulation regarding the lease of small SOEs was issued in May 1988. ${ }^{2}$ One

2. "Tentative Regulations on the Lease of Small State-Owned Industrial Enterprises," the State Council, 20 May 1988. 
direct consequence of the adoption of the lease contract was the introduction of private entrepreneurs into the management of SOEs, because managers could be recruited from outside the enterprise. When it proliferated into the countryside, leasehold in many cases led to the privatization of township and village enterprises (TVEs). This happened when the managers could retain the ownership of the capital accumulated during the lease period. After the manager leased the firm for several years, his own capital would overwhelm the capital owned by the local government, and the firm would effectively be owned by the manager himself.

In addition to contracting and leasing, other reform measures that would potentially lead to privatization were also adopted. Among them, incorporation was the most significant. In the beginning, the government restricted incorporation to be conducted only among SOEs themselves. However, private shares soon appeared. The first case of private shares occurred in three Guangzhou SOEs in 1986. In those three firms, employees bought 30 percent of the total assets of each firm. The first case of incorporation of a large SOE was in August 1988 when Shengyang Motor Corporation was transformed into Shengyang Jinbei Motors Incorporated through the issue of shares to the general public.

The opening of the Shenzhen Stock Exchange in 1990 and the Shanghai Stock Exchange in 1991 enabled SOEs to issue shares to the public widely. However, the Chinese government implemented restrictive measures to prevent the state from losing control of the newly listed SOEs. For example, it required that a certain proportion of a firm's shares not be sold.

Real privatization began after Deng Xiaoping's visit to the south in 1992. As with many other reform initiatives, privatization began with localities and was then sanctioned by the central government. The most important impetus for local privatization was the large amount of debt accumulated in the state sector. This was a more pressing problem in small cities because of their smaller economies. For example, in Zhucheng city, Shandong province, among the 150 city-owned enterprises, 103 were in the red, and the total loss was 147 million yuan, equivalent to the city government's revenue for 1.5 years (Zhao 1999). Shunde of Guangdong province had the same problem when it first started its privatization program in 1992. The solution reached by the localities was to privatize small firms, but Shunde and Zhucheng were more radical, privatizing almost all of their state and collective firms. In 1995 the central government, after several rounds of investigation and discussion, formed a policy called zhuada fangxiao, or "keep the larger and let the smaller go," which limited the state's authority to 500 to 1,000 large state firms and allowed smaller firms to be leased or sold. ${ }^{3}$

3. In 1994, as the ministry in charge of the government's economic affairs, the State Economic and Trade Commission sent a report, "Suggestions on Revitalizing Small State-Owned Enterprises," to vice premier Wu Banguo, who was in charge of enterprise reforms. In September 1995, the policy was formally announced by the central committee of the CCP in one of its plenaries and was put into the suggestions to the ninth five-year plan. 
The government had a good reason for implementing this policy. In 1997, the 500 largest state firms had 37 percent of the assets held by state industrial firms, contributed 46 percent of the taxes collected on all state firms, and accounted for 63 percent of the total profit in the state sector. On the other hand, smaller firms owned by local governments had worse performance than those owned by the central government. In 1995, 24.3 percent of the central firms were in the red, but 72.5 percent of the local firms were in the red (Zhao 1999). Therefore, "Control of the (500) largest firms means we have control of the largest chunk of the state economy."

From the "let the smaller go" part of the policy came the word gaizhi, meaning "changing the system." Starting in 1994, gaizhi began to spread to the whole country. The content of gaizhi included contracting and leasing, the two methods used before, as well as new methods such as selling to private owners, employee-holding, incorporation, listing on the stock market, restructuring of internal and external governance, and bankruptcy. By international standards, gaizhi really is privatization.

One aspect of gaizhi was to remove the "red hat" for red-hat firms - that is, firms with a collective face that were actually run privately. In March 1998, the government issued a directive requiring all red-hat firms to take off their hats by November 1998.

Sichuan provides an example of gaizhi. In 1994, the provincial government began to implement gaizhi, starting with county-owned enterprises. By the end of 1998, the province ended gaizhi for 68.6 percent of the 42,681 firms that were targeted for gaizhi. Among those transformed, 35.1 percent were transformed into employee-owned companies, 11 percent were transformed into employee-owned cooperatives, 14.3 percent were sold, 7 percent were contracted out to individuals, 8.5 percent were leased out, 7 percent were bankrupt, and 5 percent were taken over by other firms.

Privatization in general was more popular in the countryside. After 1993, many localities that had been renowned for their development of the collective economy, including Shunde and southern Jiangsu, began to implement massive privatization. TVEs used to have vaguely defined property rights that did not maintain clear-cut definitions of who- the entrepreneur or the government or both-owned the enterprises. Because of their marvelous growth records, TVEs have been hailed by some authors as posing a challenge to the neoclassical doctrine of clearly defined ownership (e.g., Weitzman and Xu 1994). However, as TVE growth slowed down in the 1990s, the disadvantages of their vaguely defined property rights were acknowledged by academic researchers. Like their urban counterparts, the SOEs, TVEs suffered a soft-budget problem (Zhang 1998). Local governments felt the problem earlier because they shouldered a con-

4. Vice premier Wu Banguo's speech in the national conference on economy, 20 December 1997. Quoted in Zhao (1999). 
siderable amount of debts accumulated by their TVEs' nonperforming loans. Financial crisis led the government to seek institutional change (e.g., North and Weingast 1989). Li, Li, and Zhang (2000) showed with a theoretical model that financial competition among local governments was a major cause of China's local privatization initiatives. The evolution of government policy toward privatization in China, especially in the 1990s, exemplified the theory. ${ }^{5}$

However, the wave of privatization initiated by gaizhi in 1998 met the criticism that it led to the loss of state assets. The government also lowered its tone on privatization. Some localities stopped their privatization programs; more of them lowered their profiles to avoid being subject to the criticism. The new constitutional amendment enacted in early 1999 elicited a new round of privatization. It was estimated that 70 percent of the SOEs had been privatized by the end of 2002 (IFC, forthcoming). By international standards, gaizhi thus qualifies as a property-rights revolution, although this revolution has been largely silent.

\subsection{Regional Disparity in Firm Performance}

Although privatization has spread cross the country, its outcome is not uniform. Liu, Wang, and Yao (2001) showed that many privatized firms in southern Jiangsu, a region once famous for its collective firms, had problems. On the one hand, asset stripping was rampant in newly privatized firms; on the other hand, the local economy had regressed to one based on small, family workshops. Qin (1998) found a similar phenomenon in this region. However, there were better performers, too. Zhucheng of Shandong province and Shunde of Guangdong province have performed quite well. In this section, we use firm-level data from a 1999 survey to assess the post-privatization performance in six cities: Beijing, Chengdu, Wenzhou, Shunde, Deyang, and Mianyang. ${ }^{6}$ Beijing is the national capital; Chengdu is the capital of the Sichuan province, located in southwest of China; Wenzhou is a prefecture-level city in southern Zhejiang province; Shunde is located in the Pearl River delta, close to Macao; and Deyang and Mianyang are two cities in Sichuan province. Except for Beijing, all the other cities are renowned for their recent development of private firms, many of which are privatized firms. The survey was designed to study China's emerging private sector, so firms included in the survey are mostly private firms. This makes the study of post-privatization performance easier, because it controls for within-firm incentive problems that frequently are found in public firms. Data on firm performance and other relevant information were col-

5. In this respect, Zhao (1999) is a nice reference.

6 . The survey was organized by IFC in 1999. For a description of the survey, see Garnaut et al. (2001). 
lected for 1995 and 1998. The total number of firms covered by the survey was 629 . However, this study is limited to the firms that provided valid information, so the sample size is smaller.

We study three performance indicators: value-added, pretax return to capital, and the growth of capital stock in the period 1995 to 1998 . We use value-added instead of output because the former is a better measure of performance; besides, we do not have enough valid data for intermediate inputs. Confined by data availability, we have to limit the study of valueadded and pretax profit rates to the year 1998. The study of the growth of the capital stock is especially interesting because it reflects entrepreneurs' confidence in the local economy. The aim of the study is to assess the performance difference between the six cities after firm-level characteristics are controlled for.

For value-added, we first run a Cobb-Douglas value-added production function with labor and capital as inputs. Value-added is measured in 10,000 yuan, labor is the number of employees of a firm, and capital is the original value of the capital stock at the end of 1998 (measured in 10,000 yuan). We do not have good data on capital depreciation so we cannot use net capital value.

In addition to the two inputs, we use other variables to control for firm efficiency. These variables can be assigned to three groups. The first is firm characteristics. These include ratio of college-and-above graduates in management, the percentage of self-finance when the firm was first established, the degree of competition in the industry, whether there are entry barriers to the industry, whether the firm is an exporter, and the firm's ownership status. The ratio of college-and-above graduates measures the stock of human capital in management and thus (partly) controls for the firm's innovative capacity. Self-finance is relative to borrowing from formal financial institutions; it includes owners' own savings and borrowing from friends and relatives. On the one hand, it controls for the constraints that a firm faces in the financial market; therefore, more self-finance may entail smaller chances of success. However, more self-finance also imposes more self-discipline on the firm and forces it to use funds more wisely. Therefore, the sign on the effect of this variable is undetermined.

Degree of competition takes three values: $1=$ heated competition, $2=$ modest competition, and $3=$ no competition. Less competition in the industry implies a stronger monopoly position for the firm in the market; we expect this variable to have a positive effect on productivity. Entry barrier is a dummy variable with a value of 1 indicating that the barrier exists, and a value of zero meaning no barrier. Entry barrier takes the form of licensing and other government approvals. Firms in an industry with entry barrier enjoy more monopoly power, so we expect that this variable would contribute positively to a firm's productivity.

Export status controls for a firm's international linkage, and it is ex- 
pected that an exporter will perform better than a nonexporter. Ownership is grouped into three categories: domestic SOEs and collective firms, domestic private firms, and foreign firms and joint ventures. The first category is used as the reference group in the regressions.

The second group of variables is city dummies. If not otherwise defined, Shunde is used as the reference city in the regressions. For the purpose of the current study, this group of variables is key to our understanding of regional performance disparities.

The third group of variables is industrial dummies. We grouped the firms into six large industries: primary (mining, logging, and agriculture); light manufacturing (food, garments, furniture, and sports and office supplies); heavy manufacturing (chemicals, metal and nonmetal refinement and manufacturing); machinery; electronics; and others. The last industry is used as the reference group.

There are 247 firms with valid data. Distribution of those firms is as follows: Beijing 116, Shunde 24, Chengdu 36, Wenzhou 32, Deyang 10, and Mianyang 29. Beijing turns out to have more firms with valid data. This is because Beijing had better organizational arrangements when the survey was implemented.

The results of the value-added production function are presented in column (1) of table 10.1. To save space, the results for the industrial dummies are not reported. The output elasticities for labor and capital are 0.99 and 0.20 , respectively, indicating weak increasing returns to scale. Among the firm characteristics, only the percentage of self-finance is significant. It has a positive sign, showing that the effect of financial discipline outweighs the effect of financial constraint. Among the city dummies, all but Deyang have a negative sign, and the coefficient for Beijing is significant. This shows that firms in Shunde might be more efficient than those in the other cities. To further explore this possibility, we rerun the regression by grouping all five cities except Shunde into one group and studying their difference from Shunde. The results are reported in column (2) of table 10.1. Although the estimate for Shunde is not statistically significant, the size of the difference is large. Firms in Shunde are 46.5 percent more efficient than firms in the other cities.

The third and fourth columns in table 10.1 report two more regressions on value-added. The dependent variable is value-added per yuan of capital. This time, a new variable - capital per worker - is added to the regression. The first regression takes Shunde as the reference city and puts in all the other city dummies. Now, all the cities except Deyang are shown to be significantly inferior to Shunde. The difference ranges from 10.4 yuan $(1.25$ dollars) to 12.5 yuan (1.50 dollars), which is substantial. The second regression then takes the previous approach, to group all the other cities together. The estimation puts the difference between Shunde and the other cities at 11.5 yuan (1.39 dollars), which is highly significant. Therefore, Shunde is far more efficient than the other cities in utilizing its capital. 


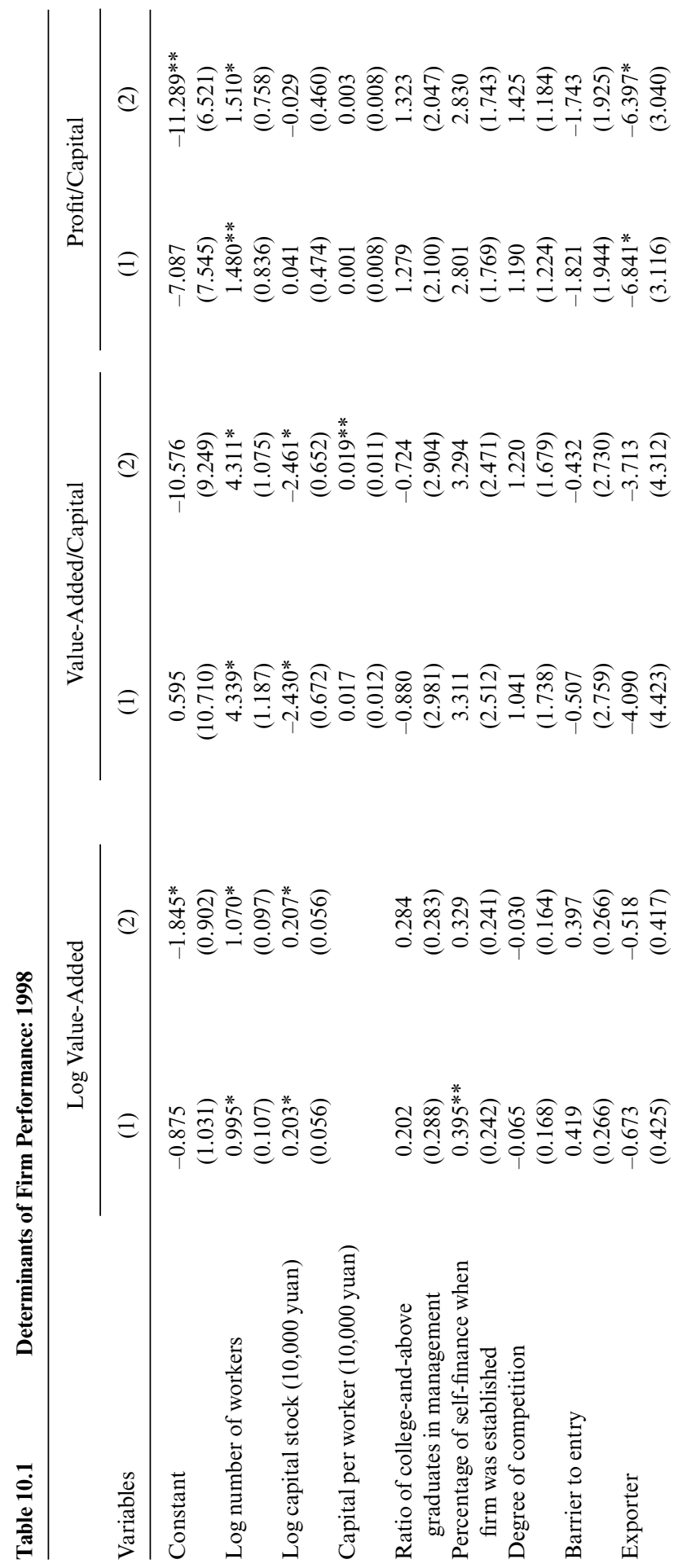




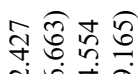

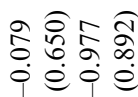

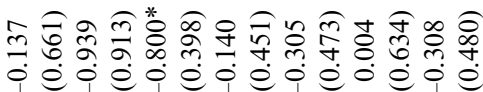

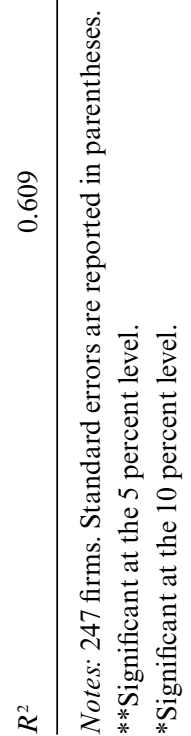

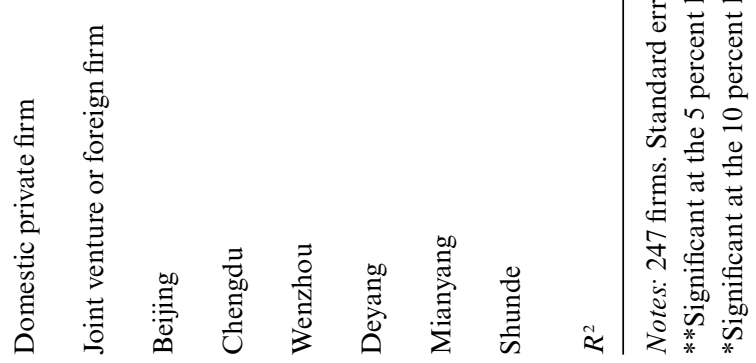


This is shown further by the estimation of pretax profit per yuan of capital. The results of two regressions are reported in the last two columns in table 10.1. The definitions of the two regressions are the same as before. In the first regression, all the other cities are shown to be slightly less efficient than Shunde. The second regression then shows that the difference between Shunde and the other cities is 4.38 yuan (53 cents), which is significant at the 10 percent significance level. It is noteworthy that an exporter is significantly less efficient than a nonexporter in terms of profitability, a result contrary to our expectation. One explanation is that Chinese exporters frequently are engaged in price competition, so their profit margins are narrowed. However, the fact that firms are still engaged in exporting shows that they might get indirect benefits such as tax returns and foreign currency retention.

Finally, the results on capital growth are presented in table 10.2. Growth is defined as (capital stock of 1998 - capital stock of 1995)/(capital stock of 1995). Because of the limitation of valid data, the sample size shrinks to sixty-three firms. On average, the firms grew 8.43 times in the three-year period. However, the variation is large. The distribution, from the highest to the lowest, is as follows: Deyang, 21.5 times (six firms), Shunde, 15.5 times (six firms), Beijing, 6.4 times (fourteen firms), Mianyang, 8.1 times (seventeen firms), Wenzhou, 4.1 times (fourteen firms), and Chengdu, 3.9 times (six firms). To maintain degrees of freedom, industrial dummies are

Growth of Capital Stock: 1995-1998

\begin{tabular}{lc}
\hline Variables & Estimates \\
\hline Constant & $18.935^{*}$ \\
Capital in 1995 (10,000 yuan) & $(7.515)$ \\
& $-0.0018^{* *}$ \\
Ratio of college-and-above graduates & $(0.0011)$ \\
in management & -1.181 \\
Percentage of self-finance when & $(5.138)$ \\
firm was established & -3.087 \\
Degree of competition & $(5.003)$ \\
& $-6.117^{*}$ \\
Barrier to entry & $(2.938)$ \\
& -2.462 \\
Exporter & $(6.476)$ \\
& $23.222^{*}$ \\
Shunde & $(7.595)$ \\
& $11.762^{* *}$ \\
$R^{2}$ & $(6.951)$ \\
\end{tabular}

Notes: 63 firms. Standard errors are reported in parentheses.

**Significant at the 5 percent level.

*Significant at the 10 percent level. 
excluded. In addition, we only explore the difference between Shunde and the other cities as a whole. However, we add the capital stock in 1995 to control for initial firm size. Understandably, the results show that capital stock in 1995 has a significantly negative effect on capital growth. Another significant result is that exporters have experienced much higher growth. Less comprehensible is the result that a firm in a less competitive industry tends to have a smaller growth rate. The most important result in terms of our concern is that Shunde has a significantly higher growth rate than other cities, with the difference being 11.8 times.

To summarize these empirical results, we find that Shunde has been consistently doing better than the other cities. The task remaining is to explain Shunde's better performance. In the regressions, we relied on the city dummies to assess regional differences, but the dummies can carry the effects of a lot of uncontrolled regional characteristics. Here we would like to concentrate on a single aspect of the problem, that is, the regularity of government administration. Privatization gives private owners legal ownership of the firm, but does not automatically guarantee that the government will protect that ownership. In this respect, Shunde has done much better than the other cities. It conducted a radical government reform concurrently with its privatization program. In the next section, we present a theoretical model to show that government commitment to the protection of private ownership is the key to successful privatization. The commitment is shown by the government's stripping of its own power. In section 10.4, we come back to the case of Shunde by presenting a description of its government reform.

\subsection{A Model of Government Commitment and Privatization}

In this section, we present a formal model explaining the relationship between government reform and firm performance. First, however, we provide a verbal description of the ideas behind the model.

Consider an economy composed of a firm, a politician, and a firm manager. The firm initially is publicly owned. The manager is delegated to managing the firm with a fixed wage, so he also provides a fixed amount of effort. A politician leads a bureaucracy of many bureaucrats and delegates to them the regulations of the firm. In the Chinese context, regulations include project approval and direct intervention into the firm's management affairs (such as employment target, wage determination, investment decisions, etc.) as well as other regular regulatory activities such as taxation, standard enforcement, and so on. However, if they are unregulated, these bureaucrats tend to be corrupt and to grab from the firm, and these regulatory functions provide a vehicle for that grab. The politician needs these functions to achieve particular goals that are valuable to him. One example is that maintaining full employment increases his popularity among a cer- 
tain portion of the population. Another example is that implementing a specific industrial policy drives out some industries (like those creating heavy pollution) that he thinks are bad for the local economy. In addition, the politician cares about the opinion of the general public and the support of his subordinates. The general public cares about the revenue of the firm, and the bureaucrats care about their "grabbing capacities." Therefore, the profit of the firm, intervention power, and the bureaucrats' grabbing capacities all enter his utility.

A governance reform is defined as the establishment of the rule of law that eliminates the bureaucrats' grabbing from the firm. The reform is different from eliminating government intervention into the firm. Under certain circumstances (such as the Mao Zedong era in China), government intervention does not necessarily lead to corruption. However, it facilitates, if not directly causes, corruption in most cases. We assume that it is at the politician's discretion whether to take the reform and eliminate his subordinates' grabbing power. Under public ownership of the firm, the manager's supply of effort does not respond to the grab, so corruption is not harmful to the politician and he will not undertake the reform.

Privatization is a shift in ownership that makes the manager the residual claimant. It does not guarantee that government intervention disappears along with the ownership shift, though. Because the manager begins to respond to the severity of the grabbing hand, corruption becomes costly to the politician, and it may be an efficient decision for him ex ante to conduct the governance reform along with privatization. More importantly, the manager will not take the firm in the first place, and privatization will fail if the governance reform is not undertaken. Therefore, the two reforms are preconditions for each other. Nevertheless, there is a critical difference between them: While the ownership reform is irreversible, the governance reform has a time-consistency problem. If the manager believed the politician and provided effort, it would be in the politician's interest to renege, in other words, to let loose the corruption. But the manager can envision this reneging behavior perfectly and will take precautions in advance, probably providing the effort that he provided under public ownership. As a result, privatization will not be an attractive choice for either the politician or the manager. This is a typical time-inconsistency and subsequent inefficiency problem in which a player cannot make a binding commitment.

However, this problem may merely arise as a result of the limited number of choices that are available to the players. In the real world, the number of choices that a player can choose from is large and once they have been made, some of them become binding constraints on the player (he may be held legally responsible to keep the choices). Even a government in a totalitarian state cannot be totally free of observing its choices. In our case, removing government intervention can be made a binding constraint (probably through the privatization contract) on the politician; if this is done, it can serve as a credible commitment for the politician to stick to the 
governance reform because, by removal of the intervention, corruption becomes more visible and its cost to the politician becomes higher.

The commitment mechanism discussed here is different from those frequently appearing in recent literature that concentrates on the decentralization of decision making (e.g., North and Weingast 1989; Qian and Weingast 1996, 1997; and Zhang and Li 1998). Here the commitment can be termed "burning the bridge," a military tactic that can be traced back to Chinese Han dynasty two thousand years ago. In one battle, General Han Xin brought his army to a big river, crossed it, and burned down the bridge over it, so that no retreating route was left for his men and the only hope for them to survive was to defeat the enemy. They did that. In this story, Han Xin had another choice: taking the army over the river (and burning down the bridges over it), in addition to killing retreating soldiers himself. The former was an automatic binding constraint on his men and himself, because retreating into the river would mean immediate death; the latter, however, was not, because even he wanted to kill all the cowards, many of whom would succeed in escaping from the messy battlefield.

\subsubsection{Settings}

The economy is composed of a firm, a politician, and a firm manager. The firm is initially publicly owned. The manager is delegated to manage the firm. We assume that public ownership makes an incentive contract infeasible for the manager. This assumption can be justified on the grounds of the soft budget constraint first proposed by Kornai (1979) and later refined by Qian (1994) and Dewatripont and Maskin (1995). Therefore, we assume that the manager provides a fixed amount of effort, $e_{0}$, for firm management. At this level of effort, the disutility to the manager is zero. Consistently, the wage that the manager gets is also normalized to zero.

In the meantime, the politician maintains a certain level of intervention $s \in[0,1]$, say, that is delegated to the bureaucrats to implement on the firm. However, the bureaucrats tend to grab from the firm if they are not properly checked. We assume that their total grab is proportional to the firm's revenue, with the proportion being $t \in[0,1]$. The grab also brings a deadweight loss to the firm. In summary, we can specify the firm's net revenue as

$$
R=\theta e_{0}-a t,
$$

where $\theta \geq 1$ is a parameter representing the firm's market conditions, and $a$ is a positive number measuring the intensity of the deadweight loss brought about by the grabbing. A larger $\theta$ implies a stronger local economy. To structure the discussion, we set a boundary condition that $R$ is nonnegative for any $t$ and $s .^{7}$

7. This assumption is inessential to our results; but since the revenue function and the politician's utility to be introduced later are both linear, we need this assumption as a boundary condition. With this boundary condition, our analysis will be simplified technically. 
The politician cares about the general public's interest, the support of the bureaucrats, and the result of the intervention. The public's interest can be represented by the size of $R,{ }^{8}$ the support of the bureaucrats by $t$, and the result of the intervention by $s$. However, corruption also has a cost to the politician, and the cost is likely to increase as $t$ becomes larger. Nevertheless, government intervention can serve as a disguise and a damagecontrol device and mitigates the cost. These concerns are best represented in the politician's utility function (all in monetary terms)

$$
U=R+\alpha_{1} t+\beta s-\left(\alpha_{2}-\gamma s\right) t,
$$

where $\alpha_{1}, \alpha_{2}, \beta$, and $\gamma$ are all positive numbers. In the equation, $\beta$ represents the weight that the politician puts on the result of the intervention, $\alpha_{1}$ represents the support of the bureaucrats, and the sum $\alpha_{2}-\gamma s$ represents the cost of corruption. Collecting and rearranging terms, we have

$$
U=R+\alpha t+\beta s+\gamma t s,
$$

where $\alpha=\alpha_{1}-\alpha_{2}$. Then $\alpha t+\gamma t s$ is the net gain from granting the bureaucrats the grabbing power. We assume that $\beta$ is larger than 1 , that is, that the politician values more of the special interests achieved by intervention than the general public's interest.

Governance reform is defined as the politician's elimination of the corruption and setting $t$ equal to zero. As the setup shows, the interests involved may prevent it from happening.

\subsubsection{Public Ownership}

Governance reform may not be desirable for the politician under public ownership of the firm. Because his utility increases monotonically with $s$, the politician will set $s$ equal to 1 . He will also set $t=1$ because his utility is linear in $t$. If that is the case, his utility is

$$
U_{0}^{c}=\theta e_{0}-a+\alpha+\beta+\gamma .
$$

With governance reform, $t$ is set equal to zero, and his utility is

$$
U_{0}^{*}=\theta e_{0}+\beta .
$$

However, setting $t=0$ may not be compatible with the politician's incentive if the following condition holds:

$$
\alpha+\gamma>a
$$

It is noteworthy that this condition has nothing to do with $\theta$, so the government of a city with a stronger economy does not have a stronger incentive to engage in governance reform than the government of a city with a weaker economy. We will show that with privatization, governance reform could oc-

8. Alternatively, one can also interpret this assumption as the politician's concern on tax revenue - a larger economy implies more tax revenue to the government. 
cur even when equation (5) holds; that is, privatization would give the politician an extra incentive to engage in the reform. On the other hand, only when the reform is carried out and committed to by the politician will privatization be a Pareto improvement to both the politician and the manager.

\subsubsection{Governance Reform and Privatization}

Privatization shifts the ownership of firm from the government to the firm manager and makes the latter the residue claimant. ${ }^{9}$ We let the politician and the manager play the following game.

On day 1 , the politician announces whether to privatize the firm and determines the level of intervention in the firm. On day 2 , the manager decides whether to accept the offer of privatization and, if he does, how much effort to put into the firm. On day 3 , the politician decides whether to engage in governance reform and the production is carried out.

We assume that privatization and the politician's decision about intervention in the firm are irreversible and observable by the manager. We put the politician's decision about governance reform after the manager's effort to capture the nonenforceability of the reform. To wit, it may be an ex ante optimal decision for the politician to engage in the reform (i.e., to set $t$ be zero), but if the manager believed the politician and acted accordingly, it would be in his interest to renege and give up the reform afterward (i.e., to revert to corruption). However, the manager can well envision the politician's time-inconsistency problem and act accordingly. Like the feature shared by the time-consistency literature, this will result in inefficient outcome. In what follows, we will first replicate this standard result and then propose two commitment mechanisms that the politician can use to commit himself to his ex ante efficient decisions.

We start with the politician's ex ante efficient decisions on day 1. In making these decisions, he takes into account the manager's response to the grabbing hand because the latter now becomes the residual claimant of the firm. For any level of effort $e$, the disutility (in monetary terms) to the manager is $(1 / 2) \mu\left(e-e_{0}\right)^{2}$, where $\mu$ is a positive number. He maximizes his net profit $\pi=(1-t)(\theta e-a t)-(1 / 2) \mu\left(e-e_{0}\right)^{2}$ by choosing his effort $e$. This immediately gives us a solution to $e, e(t)=\theta(1-t) / \mu+e_{0}$. Taking this for granted, the politician maximizes his utility by choosing $t$ and $s$, that is, he solves the following problem:

$$
\max _{s, t} U=[\theta e(t)-a t]+\alpha t+\beta s+\gamma t s
$$

The optimal solution to $s$ is still 1. To make governance reform (i.e., $t=0$ ) attractive to the politician, we need that the marginal utility of $t$ be negative, that is,

9. Implicitly, we assume that the firm is given to the manager for free. While it could be justified by empirical findings on Russia and to some extent, on China (Garnaut et al. 2001), this assumption is made to simplify our analysis and allows us to concentrate on the incentive effect of privatization. 


$$
\alpha+\gamma<\frac{\theta^{2}}{\mu+a} .
$$

The left-hand side of this condition is the marginal benefit of corruption, and the right-hand side is the marginal cost of corruption that includes the deadweight loss and an extra cost due to the manager's lost incentive. The inequality may hold even if equation (5) holds. Therefore, governance reform is easier with privatization than under public ownership. This is because now the manager's effort responds to the grabbing hand and an increase in $t$ causes an extra cost of a factor $\theta^{2}$ due to the manager's lost incentive. It is noteworthy that government reform is easier under a larger $\theta$, in other words, a city with a more prosperous local economy will be more likely to take the reform.

If equation (7) holds, $t$ is set to 0 at which the manager's supply of effort is $e^{*}=\theta / \mu+e_{0}$, and the politician's utility is

$$
U^{*}=\frac{\theta^{2}}{\mu}+\theta e_{0}+\beta .
$$

Obviously, $U^{*}$ is greater than $U_{0}^{*}$. Under equation (7), $U^{*}$ is also greater than $\mathrm{U}_{0}^{c}$. Therefore, privatization makes the politician better off if he can commit himself to the governance reform. On the other hand, the surplus left to the manager is all the firm's revenue $\theta^{2} / \mu+\theta e_{0}$, so his net utility is $\theta e_{0}+0.5 \theta^{2} / \mu$, which is positive. Finally, the general public is also pleased because the firm's revenue increased from $\theta e_{0}-a$ to $\theta^{2} / \mu+\theta e_{0}$. Therefore, we have the following proposition:

PROPOSITION 1. If the politician can commit to governance reform, privatization will be a Pareto improvement to the politician, the manager and the general public.

However, governance reform may not be time consistent for the politician, because if the manager spent $e^{*}$ on day 2 , he might gain by loosening his control on his subordinates on day 3. To examine this possibility, we note that the marginal utility of $t$ on day 3 is the same as in the case before privatization, which is positive by equation (5). Therefore, sticking to governance reform is not an ex post optimal choice for the politician. Of course, the manager can readily envision the politician's opportunist behavior and would have not provided $e^{*}$ on day 2 . Since the tax rate under corruption is 1 when the number of bureaucrats is large, the manager will provide $e_{0}$, exactly what he did under public ownership. Hence, both the manager and the politician are made indifferent between public ownership and privatization. Therefore, we have the following proposition:

PROPOSITION 2. Without commitment to governance reform, privatization will not be a better choice for both the politician and the manager. 
Propositions 1 and 2 create a dilemma for the politician. To resolve the dilemma, the politician has to make a credible commitment on day 1 assuring the manager that he will stick to governance reform. This can be done by setting $s$ equal to zero. When $s$ is zero, the marginal utility of $t$ on day 3 becomes $-a+\alpha$, which is negative if

$$
\alpha<a .
$$

This condition implies that the weight of the bureaucrats' support is less than the intensity of deadweight loss caused by grabbing if corruption is exposed because of open government intervention. Whether this is true depends on the politician's preference and the severity of the deadweight loss, yet it is clear that it can happen even when equation (5) holds. The politician's utility under commitment is

$$
U^{* \prime}=\frac{\theta^{2}}{\mu}+\theta e_{0}
$$

which is smaller than $U^{*}$. That is, commitment is costly to the politician. However, his utility still can be larger than the most he can get under public ownership, $\mathrm{U}_{0}^{c}$, if the following condition holds

$$
\alpha+\beta+\gamma<\frac{\theta^{2}}{\mu}+a .
$$

The left-hand side is the cost of privatization and commitment, and the right-hand side is the gain from it. So the condition requires that the gain be larger than the cost. If this condition holds, the manager still gets $\theta e_{0}+$ $0.5 \theta^{2} / \mu$, the same as what he gets when there is no commitment problem. The revenue of the firm also reaches the highest $\theta e_{0}+\theta^{2} / \mu$.

This is a good time to reiterate the conditions under which the commitment problem arises and can be overcome. They are conditions in equations (5), (9), and (11). The permissible parameter region defined by these three conditions is shown in figure 10.1. Notice that the size of the region depends on the relative sizes of $\theta^{2}$ and $\beta$. If the latter is greater than the former, then the permissible region vanishes. Therefore, the robustness of the local economy and the weight that the politician puts on special interests and goals are critical. Thus, we have the following proposition:

PROPOSITION 3. Commitment to governance reform can happen only if the local economy is robust andlor the politician cares less about special interests.

\subsection{Government Reform in Shunde}

The government reform in Shunde began in 1993 and ended in 1999. It was radical by any measure. It was a top-down reform starting with the municipal government itself. It downsized the government by nearly half 


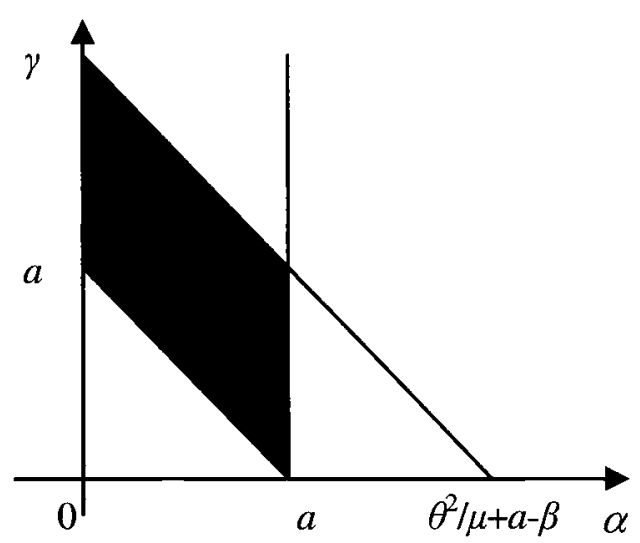

Fig. 10.1 Permissible parameter region for proposition 3

in terms of the number of government agencies and by a quarter in terms of the number of employees, transformed the functions of the government, increased the transparency of government administration, and enhanced the rule of law. In this section, we first provide a description of the reform, and then analyze the factors leading to its success, putting the emphasis on its linkage with privatization. At the end of the section, we conclude with a discussion of future problems.

\subsubsection{Accomplishments of the Reform}

The major pieces of the Shunde government reform are consolidation of government agencies and downsizing, transformation of government functions, establishment of administrative transparency, and enhanced efficiency and rule of law. Before the reform, there were 62 regular government agencies and more than 100 temporary agencies in the municipal government. The reform trimmed the number of regular agencies to 36 and eliminated 80 temporary agencies (Jiang 1999). All the intermediary committees between bureaus and the mayor were eliminated, and many bureaus with similar functions were combined. The most radical act was to combine the parallel departments in the government and the party organ. For example, the government secretary office was combined with the party secretary office; the Department of Organization and the Department of Veteran Leaders in the party organ were combined with the Department of Personnel in the government; and the party discipline committee was combined with the Bureau of Inspection in the government. The party organ is an indispensable entity in Chinese politics and government administration. Important government policies and directives are determined by the standing committee of the Communist Party, and the government's responsibility is only implementation. The consolidation of government and 
party departments enhances the characteristics of a party-state and its long-term merits can be much disputed, but it is a practical choice to downsize the government precisely because the Shunde reform was confined by China's party-state establishment.

In addition to cutting the number of government agencies, Shunde's government reform also took a tough position on government employees. Before the reform, there were 1,235 employees in the municipal government; the reform made a 25.8 percent cut and downsized the government to only 916 employees. This is really a small government in terms of the city's own population of 1.2 million and a similar population of migrants. However, the 319 employees who left the government were not simply laid off; 284 of them were transferred into newly founded businesses that had been transformed from government agencies, 15 people took early retirement, 8 people were transferred to townships, and only 12 people found their own employment. As a result, the resistance to the reform was lessened considerably. The real test, however, was the 123 officials whose ranks were lowered or even stripped off (Jiang 1999).

The downsizing not only could meet the resistance of those who lost their privileges, but also constituted a potential conflict with higher government establishments. A standard practice in China is that lower-level governments have to have the same, if not more, departments that a higher government has. The elimination and consolidation of departments in Shunde thus raised potential conflicts with the Guangdong provincial government. The way that this problem was solved was that each remaining department assumed more responsibilities and the work intensity of the remaining employees increased dramatically.

Downsizing the government cannot be sustained if its functions are not transformed. Shunde teaches us a lesson on that. In 1984, it had a government reform that cut nine government agencies and 171 people. However, because the government was still deeply involved in the management of the economy, the size of government quickly increased again. By 1987, the number of agencies increased by ten, to sixty-six, and the number of employees increased by 378, to 1,299 (Jiang 1999). The 1993 reform not only consolidated government agencies but also stripped many functions once assumed by the old agencies. This was made possible by the ownership reform. Before the reform, the government needed one bureau to manage the municipal-level firms and another bureau to provide administrative guidance to firms at the township and village levels. It also had separate bureaus in charge of domestic trade, international trade and cooperation, customs, rural trade, and tourism. After the reform, the two bureaus in charge of industry were combined into the Bureau of Industrial Development, and the other bureaus in charge of trade issues were combined into the Bureau of Trade Development. Together with the consolidation, the functions of these bureaus were reduced considerably. For example, the new industrial 
bureau no longer had the power to interfere with the internal management affairs of the old municipal firms, most of which have been privatized. Since their functions have been reduced, the industrial and trade bureaus are in the process of merging into one bureau.

The reform has reduced the government's role in economic management to a minimum, but the government has not become a figurehead. The Shunde government still maintains an active role in attracting investments, creating jobs, enforcing government regulations, providing local public goods, and managing an active industrial policy. This last function is directed mainly toward environmental protection. Shunde has large textile, dyeing, and tile industries that pollute heavily. As income increases, public demand for clean water and air has increased considerably. The Shunde government consciously rejects projects in these industries and uses taxation to force small labor-intensive and polluting firms out of business. This definitely affects employment, but it is unknown how serious the adverse effect is.

One striking change after the reform is the increase in transparency and efficiency in the Shunde government's administration. This is exemplified by its reform of its project approval process. The rule in China is that the government has the power to determine whether a project is worthwhile for the economy. The provincial-level government and cities designated to have separate fiscal plans can approve a domestic project with an investment of less than 30 million yuan renminbi, or a foreign direct investment project with an investment of less than 30 million U.S. dollars; beyond that, the project has to be approved by the central government. To get a project approved and the firm established, the owner has to have the patience to go through the maze-like government bureaucracy, spending considerable amounts of time and financial resources. The Shunde government cannot break the rule of approval, but has substantially increased the transparency and effectiveness of the approval process. Their innovation was to establish one approval office that provides "one-stop" approval for a project: it has the power to hand over the approval and is also responsible for preparing all the necessary documents for the project. This saves tremendously on the owner's efforts and increases the transparency of the approval process.

Another sign of transparency is the monthly administrative bulletin Shunde Administrative Affairs, published by the government. The bulletin publishes the newest laws and regulations issued by various levels of government and is sent to larger firms as well as to public venues, like hotels. This bulletin is unique among Chinese cities and serves as a bridge between the government and the private sector.

In relation to economic performance, the most important change brought about by Shunde's government reform is the increased regularity of government administration and the enhanced rule of law. This is shown 
in the IFC survey. To the question of how many major changes to laws, regulations, or policies took place in the last three years that affected a firm's business, the average answer in Shunde was 0.36 while the average for all the six surveyed cities was 2.54. In particular, Beijing had 6.19 times. Although Shunde's government levies were not the lowest among the six cities, they were certainly the most stable. For example, for fees (the most variable part of government levies), its coefficient of variation was 0.84 for Shunde, but in the range of 1.30 to 1.77 for the other five cities (Zhi 2001). Therefore, the policy environment is much more predictable in Shunde than in other cities. In addition, more people in Shunde than in other cities trusted the court when they had a dispute. There were 40.6 percent of the firms in Shunde that checked "going to the court" as a solution to a dispute, while the average for all the cities was 30.7 percent.

\subsubsection{Factors Leading to the Success of the Reform}

The success of the Shunde government reform is closely tied to its ownership reform, a visionary and strong leadership, a prosperous local economy, and meticulous design of the reform. As the review in the last section showed, the ownership reform was brought about by the financial problems faced by the public firms. Our theoretical model in section 10.3 then showed that ownership reform creates conditions for government reform. This is because, on the one hand, ownership reform makes firm managers the residual claimants, so they become sensitive to irregularities in government administration and law enforcement. On the other hand, ownership reform dispenses with many government functions. Both increase the politician's costs to maintaining a large and loosely controlled government, so his incentive to launch government reform is enhanced. In return, government reform sets down a credible commitment to better state governance and reduced corruption, so privatization results in good firm performance. As a result, government reform and privatization create a synergy for a better economy.

In addition to the conditions created by privatization, the role played by Shunde's leadership was also indispensable in bringing about the government reform. Our theoretical model predicts that the politician's preference is an important factor in determining the possibility of the reform. In Shunde, the reform-oriented leadership played a pivotal role in its ownership and government reforms. The party secretary is young, open-minded, and determined to engage in reform. Under his influence, the whole leadership team adopted a new philosophy toward government administration; that is, the government should draw away from direct engagement in economic affairs and instead should concentrate on the provision of public goods (including the provision of a fair, just, and open competitive environment) and implementation of the law. After several years of reform efforts, this new philosophy has gained popularity in the government and 
provided an important informal constraint on the behavior of government officials. No matter how thorough the reform is, the formal rules thus established still would be incomplete and government officials still would be empowered with a considerable degree of discretion in their decision making. Under this situation, informal constraints such as the new philosophy established in Shunde become important. One example of the effect of this informal constraint is the failure of the Bureau of Industrial Development to establish a small and medium-sized enterprise (SME) service center that was to provide charged services to SMEs. The bureau sent the proposal to the government office for screening before it was sent to the mayor for approval. The government office, staffed with junior officials, rejected the proposal and did not send it to the mayor. The message was simple: charged services could become a jumping-off board for corruption and should not be encouraged. The decision of the government office was not consistent with the rule of hierarchy commonly found in the Chinese bureaucracy, but instead was consistent with the new philosophy in Shunde.

The third factor contributing to Shunde's success is that it has a viable local economy. Although many firms were in the red when Shunde's privatization program began in the early 1990s, their losses were not created by their nonviability in the market, but rather by their mismanagement. Shunde is a production base for China's home electronics, an industry with continuously expanding domestic and international demand. Governance reform involves a trade-off between decreasing bureaucratic support and increasing social output. But a better local economy makes it easier for social output to increase, so, as our theoretical model predicts, the politician's willingness to engage in the reform is enhanced. In addition, a better local economy also makes layoffs easier as the private sector is more capable of absorbing the laid-off workers.

The last factor contributing to Shunde's success is its well-designed reform plan. This plan was not formed from the very beginning, but has been revised and enhanced in the course of the reform. Laid-off workers were not simply thrown out of the government; instead, they were first put into government-supported companies in the transition period. Afterward, these companies were privatized and the workers gradually were absorbed by the private sector. For workers remaining in the government, a major measure for boosting their morale was to increase their wages. The income of a government employee is now above the average in the private sector. However, even this wage is not enough to balance a person's desire for corrupt income. As a complement, the Shunde government maintains an active promotion system that puts able officials into important positions. In addition, the new administrative philosophy gives government officials a sense of honor as well as responsibility, which plays an important role in guarding the integrity of the administration. 


\subsection{Conclusions}

The transition from a planned economy to a market economy is not merely a transformation of ownership, but also a transformation of state governance. In Eastern Europe and the former Soviet Union, the transformation of ownership was accomplished almost overnight, but initial performance records were uniformly bad. After almost a decade, some countries (such as Poland and the Czech Republic) have improved their performance records, but many of them (especially those in the former Soviet Union) are still in deep trouble. As Shleifer (1997) pointed out, the diverse performance records in Poland and Russia were a result of their different types of state governance, especially in the area of rule of law. The Shunde experience provides yet another example.

The problem with Russia is not so much with its economy, but rather with its state governance. In particular, the dissolution of the Soviet Union and the fall of the communist regime created a power vacuum. In the process of filling this vacuum, special-interest groups and monopolists have captured the state. China is luckier than Russia for not having gone through the destruction of the state apparatus. The danger, of course, is that without that destruction, China may be stuck with the old system and may never be able to build a sound state governance structure. In this regard, privatization as forced by financial problems may well provide an opportunity for China to take on serious governance reform, starting with the government itself. Right now, government reform at the central level is finished; the central government has reduced its size by 15 percent, and twenty ministries have been eliminated. Reform at the local level is underway and radical downsizing is expected. With China's economy being privatized continuously, the government reform may well be sustainable, so the synergy of a private-ownership-based economy and a sound state governance structure can be formed.

\section{References}

Dewatripont, Mathias, and Eric Maskin. 1995. Credit and efficiency in centralized and decentralized economies. Review of Economic Studies 62 (4): 541-555.

Garnaut, Ross, Ligang Song, Xiaolu Wang, and Yang Yao. 2001. Private enterprise in China. Canberra: Asia Pacific Press at Australian National University.

International Finance Corporation. Forthcoming. Privatization in China. Washington, D.C.: World Bank.

Jiang, Zhongzuo. 1999. Institutional change in economic development: Theoretical and empirical studies based on Shunde's experience. Ph.D. diss. College of Economics and Trade, Agricultural University of Southern China, Guangzhou. 
Kornai, Janos. 1979. Resource-constrained versus demand-constrained systems. Econometrica 47 (4): 801-819.

Li, Shaomin, Shuhe Li, and Weiying Zhang. 2000. The road to capitalism: Competition and institutional change in China. Journal of Comparative Economics 28 (2): 269-292.

Liu, Yigao, Xiaoyi Wang, and Yang Yao. 2001. The social and economic dynamics of the Chinese village. ShijiaZhuang, China: Hebei Renmin Press.

North, Douglass, and Barry Weingast. 1989. Constitutions and commitment: The evolution of institutions governing public choice in seventeenth-century England. Journal of Economic History 49 (4): 803-832.

Qian, Yingyi. 1994. A theory of shortage in socialist economies based on the "soft budget constraint.” American Economic Review 84 (1): 145-156.

Qian, Yingyi, and Barry Weingast. 1996. China's transition to markets: Marketpreserving federalism, Chinese style. Journal of Policy Reform 1 (2): 149-185.

. 1997. Federalism as a commitment to reserving market incentives. Journal of Economic Perspectives 11 (4): 83-92.

Qin, Hui. 1998. Case studies on TVE privatization in Juangsu and Zhejiang. Hong Kong: Chinese University of Hong Kong Press.

Shleifer, Andrei. 1997. Government in transition. European Economic Review 41 (3-5): 385-410.

Weitzman, Martin, and Chenggang Xu. 1994. Chinese township village enterprises as vaguely defined cooperatives. Journal of Comparative Economics 23 (1): 121145.

Zhang, Gang. 1998. A study on township and village enterprises. Ph.D. diss. Stockholm School of Economics, Stockholm, Sweden.

Zhang, Weiying, and Shuhe Li. 1998. Regional competition and the privatization of Chinese SOEs. Economic Research 1998 (12): 13-22.

Zhao, Xiao. 1999. Competition, public choice, and privatization in China. China Center for Economic Research Working Paper Series C1999025. Beijing University, Beijing, China.

Zhi, Zhaohua. 2001. Privatization, government reform, and regional economic development. Master's thesis, China Center for Economic Research, Beijing University, Beijing, China.

\section{Comment David D. Li}

This paper addresses the issue of when privatization works or fails to work. This is a very important issue because in reality, privatization programs often fall short of expectations in improving enterprise performance and in enhancing social welfare, and may even backfire and lead to back-sliding of the overall reform program. More importantly, the issue is more relevant than the issue of whether privatization should be implemented but has attracted less research so far. Understanding the issue well is critical to better design of privatization programs.

David D. $\mathrm{Li}$ is associate professor of economics and associate director of the Center for Economic Development at Hong Kong University of Science and Technology. 
The issue of when privatization works arises from the fact that privatization is only a nominal transfer of ownership from the government to private hands. There is no guarantee that after privatization, the government, being the strongest player in most economies, continues to lend a heavy hand in the actual decisions of the private enterprises. Neither is there assurance that other parties, for instance, managers of enterprises who are not owners, take advantage of the retreat of the government and encroach on the control rights of the new owners.

Existing wisdom points to three general sets of conditions that induce success of a privatization program. The first is solid legal institutions that help define the rights of property owners. With the benefit of such institutions, new owners of privatized enterprises can expect to exercise their control rights in order to implement necessary changes for improving the performance of the enterprise. Of course, emerging market economies, which usually hope to establish functioning legal institutions via rapid privatization, can only wish such mechanisms were in existence.

Without the benefit of the rule of law, one alternative is to select suitable new owners to take over the privatized enterprises from the government. Suitable owners are ones who are strong enough to fend off postprivatization government interventions and guard against managerial abuses. One class of candidate is foreign corporations that are large and mobile and therefore are better positioned than domestic owners.

This paper provides a new perspective on this issue. The central message is that the government can and should precommit to certain mechanisms before privatization. With the precommitted mechanism, it is more difficult for the government to interfere in the operation of privatized enterprises and therefore improved performance of the privatized enterprises is more likely.

At an abstract level, the message makes a lot of intuitive sense and it is interesting to see it delivered in a coherent theoretical framework. We often do see that successful privatization is preceded or accompanied by major reforms of the government. Failed privatization programs are often those that were single-mindedly intended to privatize enterprises without concurrent reforms.

However, what exactly are the commitment mechanisms? This paper stops short of making this explicit. From the context of the discussion, these mechanisms might include shrinking the scope of control of the government, reducing the size of the government, simplifying regulatory setup of the government, and others. Yet, in reality, these different measures of reform have different implications for the post-privatization operation of enterprises. It helps sharpen the predictions of the theoretical model if the paper makes explicit the assumptions of which mechanisms it refers to.

The thrust of the theoretical model comes from the assumption that the commitment that the government makes and the difficulty with which the 
government interferes in the operation of the privatized enterprise are complementary. That is, the more commitment the government makes, the more difficult for the government to interfere. Again, it helps to be specific on this assumption. What kind of interference does the paper refer to? Why does such interference become more difficult for the government to make? Why, with stronger precommitment, is the interference more costly to the government?

The power of a theory lies in its ability to generate testable predications. This paper is no exception. By raising the issue of precommitment before privatization, the paper makes intuitive appeals but lacks a sequence of predictions for the reader to chew on and for future empirical work to test. The lack of more specific reference to the key assumptions leads to the lack of specific predictions. I believe that future research in this area will benefit from this line of exploration. 